\title{
Effects of thinning and fertilization on soil respiration in a cottonwood plantation in Iceland
}

\author{
J. Á. Jónsson ${ }^{1}$ and B. D. Sigurdsson ${ }^{2}$ \\ ${ }^{1}$ East Iceland Natural History Institute, 740 Neskaupstadur, Iceland \\ ${ }^{2}$ Agricultural University of Iceland, 112 Keldnaholt, Reykjavik, Iceland \\ Received: 29 June 2009 - Accepted: 3 September 2009 - Published: 24 September 2009 \\ Correspondence to: B. D. Sigurdsson (bjarni@ Ibhi.is) \\ Published by Copernicus Publications on behalf of the European Geosciences Union.
}

\begin{abstract}
The main goal of this research was to determine the short-term effects of forest management practices (precommercial thinning and fertilization) on carbon efflux of a young black cottonwood (Populus trichocarpa) plantation in southern Iceland. Changes 5 in leaf area index, tree growth, soil and air temperature were also monitored. Traditional precommercial thinning $(50 \%)$ had little effect on soil temperature, but heavy thinning $(80 \%)$ led to higher soil temperatures in spring and summer, but not much difference in winter. Thinning did not change foliage nutrient content or tree growth in the first treatment year. Effects on soil respiration were surprising; even if soil temperature was

10 slightly higher and all organic material was left at site after precommercial thinning, soil respiration in the thinned stands was significantly lowered. Fertilization increased foliage nutrient content, but did not significantly change tree growth during the first growing season following spring application. It did however significantly increase soil respiration rate in the first treatment year. These results may be important when the effects of early forest management on carbon fluxes are modeled.
\end{abstract}

\section{Introduction}

Anthropogenic activities have increased greenhouse gas emissions, especially carbon dioxide $\left(\mathrm{CO}_{2}\right)$, yielding an annual accumulation of carbon $(\mathrm{C})$ in the atmosphere at the rate of $2.8 \mathrm{PgCy}^{-1}$ (Fan et al., 1998). As a result, the surface air temperature has 20 been rising steadily and it has been suggested that even more drastic changes will occur in the future (IPCC, 2007). Soil respiration is of particular importance as it is the largest terrestrial source of $\mathrm{C}$ to the atmosphere, contributing 80.4 $\mathrm{Pg} \mathrm{Cy}^{-1}$ (Raich et al., 2002). Hence, small changes in terrestrial soil respiration could have significant effects on atmospheric $\mathrm{CO}_{2}$ concentration. Furthermore, a positive correlation has been demonstrated between temperature and soil respiration (Knorr et al., 2005a). Higher temperatures could therefore increase soil respiration to the atmosphere that further 
exacerbates global warming (e.g. Kirschbaum, 1995; Knorr et al., 2005a). However, it has been pointed out that this effect could be reduced through increase in primary production in nutrient limited ecosystems, as nutrient availability is expected to increase with higher temperature (e.g. Liski et al., 1999; Jarvis and Linder, 2000). At a hectare

5 scale, similar changes occur when managed forests are thinned. The decreased leaf area index changes the microclimate at the forest floor which affects soil processes, such as decomposition and respiration activity (Siira-Pietikäinen et al., 2001; Hyvönen et al., 2007).

Soil respiration can be partitioned into two processes, metabolic activity of plant roots 10 (autotrophic respiration) and the decomposition of dead organic material (heterotrophic respiration) (Ryan and Law, 2005). Autotrophic and heterotrophic respiration can respond independently to a number of factors, such as climate, soil type, forest type and human disturbances (Boone et al., 1998; Hanson et al., 2000; Knorr et al., 2005a; Olsson et al., 2005; Luo and Zhou, 2006). Probably because of the diverse and complex 15 nature of these interactions, studies focusing on the effect of forest management practices on soil respiration have given ambiguous results. For instance, soil respiration has increased (Selmants et al., 2008), decreased (Tang et al., 2005; Sullivan et al., 2008) or stayed unchanged (Toland and Zak, 1994) following thinning. Fertilizer applications to forest soils have yielded similar responses, with reduction (Olsson et al.,

20 2005), increase (Cleveland and Townsend, 2006) or no change (Castro et al., 1994) in soil respiration. Therefore, more work is needed to fully understand what are the general responses to such management practices.

It is of special interest to study the impacts of forest management on soil organic matter (SOM) in Iceland. Previous research has indicated that Icelandic forest soils can store twice the amount of $\mathrm{C}$ as aboveground woody biomass (Snorrason et al., 2002) and that the rate of $C$ sequestration in SOM, fine roots and litter can be as high or higher than accumulation in woody biomass during the establishment phase after afforestation (Bjarnadóttir, 2009).

The aim of this study was to determine the short-term effects of precommercial 9259

thinning and fertilization on carbon efflux of a young black cottonwood (Populus trichocarpa) plantation in southern Iceland. Black cottonwood is the 2nd most used broadleaved tree species in afforestation in Iceland, following the native mountain birch (Betula pubescens). It was expected that precommercial thinning of a young 5 broadleaved plantation would lead to higher soil respiration due to higher soil temperatures and increased litter input and that the size of the response would depend on the thinning intensity. Fertilization was expected to further increase soil respiration.

\section{Material and methods}

\subsection{Site description}

10 The experimental site is located in Gunnarsholt in southern Iceland $\left(63^{\circ} 51^{\prime} \mathrm{N}\right.$ and $20^{\circ} 13^{\prime} \mathrm{W}$, elevation $78 \mathrm{~m}$ ). In 1990 cuttings of a single clone of black cottonwood (Populus trichocarpa Torr. and Gray; Clone Idunn) were planted in an abandoned hayfield from which the sod had been removed in 1989. A total of 145000 propagated cuttings were planted in 14.5 ha with $1 \mathrm{~m}$ spacing (stand density of 10000 trees ha ${ }^{-1}$ ). The

15 Idunn-clone originates from the Copper River Delta region, Alaska (Lat 60-61 ${ }^{\circ}$ ); an area with similar climate as Gunnarsholt (Sigurdsson, 2001).

A microclimatic station was installed at the centre of the site in 1989, where a range of climatic parameters, including air temperature, soil temperature and global radiation, were monitored (Aradottir et al., 1997). The soil is an Andisol (found only in volcanic 20 areas) and silty loam in texture. The soil water potential is permanently close to field capacity, and water availability therefore not considered to limit tree growth at the site (Strachan et al., 1998). Organic carbon content of the A1 soil layer ranged between 1.8 to $2.4 \%$, pH was 5.8 and cation exchange capacity (CEC) was 19 meq $100 \mathrm{~g}^{-1}$ (Strachan et al., 1998).

25 The most limiting environmental factor for tree growth at the site has been found to be nitrogen availability (Sigurdsson et al., 2001). The stand development was slow in 
the beginning, but after the saplings had overgrown the competing vegetation and the most active frost layer in 1997, the average annual height increment has been $33 \mathrm{~cm}$. The average tree height, diameter at breast height and basal area across the whole plantation in autumn 2003 were $3.1 \mathrm{~m}, 2.7 \mathrm{~cm}$ and $5.9 \mathrm{~m}^{2} \mathrm{ha}^{-1}$, respectively. More

5 information about the climate, soil and other physical conditions at the site can be found in Strachan et al. (1998) and Sigurdsson (2001).

\subsection{Experimental design}

In June 2004, 24 plots were established in the experimental plantation, each 0.06 ha $(25 \times 25 \mathrm{~m})$. The plots were arranged in a randomized block design with thinning in10 tensity and fertilization as main factors. Treatments consisted of unthinned control $\left(10000\right.$ trees ha $\left.^{-1}\right), 50 \%$ thinned $\left(5000\right.$ trees ha $\left.^{-1}\right)$ and $80 \%$ thinned $\left(2000\right.$ trees ha $^{-1}$ ) on either unfertilized soil or where all macro- and micro-nutrients were applied in early June as $80 \mathrm{~kg} \mathrm{Nha}^{-1}$ and with other elements in optimum proportions for black cottonwood (Linder, 1995; Sigurdsson, 2001). The treatments were entitled C-00, F-00,

$15 \mathrm{C}-50, \mathrm{~F}-50, \mathrm{C}-80$ and F-80 for the three thinning intensities (00\%, 50\%, 80\%) and two nutrient treatments $(\mathrm{C}$ and $\mathrm{F})$, respectively. All thinned trees were left on the forest floor to decompose.

\subsection{Leaf morphology and chemical analysis}

To check if trees had increased their nutrient uptake following spring fertilization, 20 youngest fully expanded leaves on top shoots were excised from 20 trees in each nutrient treatment in late-August 2004. The leaves were placed directly on ice and thereafter stored at $-18^{\circ} \mathrm{C}$ to await further processing. Six leaves from each treatment were randomly chosen for morphological analysis, scanned on a pre-calibrated scanner and analyzed for area, length and width with the WinFOLIA image analysis 25 program (WinSeedle, Regent Inc., Canada). Thereafter the leaves were dried at $85^{\circ} \mathrm{C}$ for $48 \mathrm{~h}$ and weighed. Specific Leaf Area (SLA; $\mathrm{cm}^{2} \mathrm{~g}^{-1}$ ) was then calculated for each

9261

leaf. The other leaves were used for chemical analysis. They were dried in the same way, ground and sent to the Centre of Chemical Analyses (Efnagreiningar Keldnaholti), ICETEC, Reykjavik, Iceland, where their total nitrogen was measured by Kjeldahl wet combustion on Tecator Kjeltec Auto 1030 Analyzer.

\section{$5 \quad 2.4$ Growth measurements}

At the start of the experiment, in June 2004, diameter at breast height (DBH) was measured for all trees in treatment plots. The results were used to randomly choose five "mean trees" in each plot for further measurements of stature and growth. Additional measurements on those trees included height, length of the leader shoot, crown 10 surface area, crown height and stem diameter at $50 \mathrm{~cm}$ height.

\subsection{Leaf area index measurements}

Leaf area index (LAI) of overstory trees was measured with a pair of LAI-2000 Plant Canopy Analyzers (LI-COR Inc., Lincoln, Nebraska) on an overcast day (only diffused light) in early August 2004. One instrument was placed outside the forest and the 15 other was used to take readings of sky brightness at nine fixed points within each treatment plot. The sensor heads always faced north, a $180^{\circ}$ lens cap was used and the calculations of LAI was limited to the hemispherical area above $23^{\circ}$, due to relatively small plot size.

\subsection{Soil respiration measurements}

20 Eight $5 \mathrm{~cm}$ deep PVC collars with $100 \mathrm{~mm}$ inner diameter were inserted ca. $3 \mathrm{~cm}$ into the soil surface in each treatment plot in early June 2004. Soil respiration was receptively measured from each collar with closed-chamber CIRAS gas analyzer (PPSystems, Hitchin, Hertfordshire, UK) during the 2004 growing season. Each measurement lasted for $1.5 \mathrm{~min}$ and respiration rate was calculated by applying a linear func25 tion to the rise in $\mathrm{CO}_{2}$ concentration that was measured once per $1.6 \mathrm{~s}$. Measurement 
campaigns were carried out 22-30 June, 28 July, 16 August and 22 September. Soil temperatures at 5 and $10 \mathrm{~cm}$ depth were also simultaneously measured. On 28 July, only 3 out of 4 blocks could be measured due to instrument failure.

\subsection{Climate and soil temperature measurements}

5 Air and soil temperature were constantly monitored in the three thinning treatments by six HOBO dataloggers (Onset Computer Corporation, Pocasset, MA, USA) and sensors made out of copper-constantan thermocouples. Soil temperature was measured at $10 \mathrm{~cm}$ depth and air temperature at $50 \mathrm{~cm}$ height and stored as $30 \mathrm{~min}$ averages. Other climatic variables, including irradiance, air temperature, relative humidity, precip-

10 itation, wind direction and speed, were measured continuously and stored as $30 \mathrm{~min}$ averages at the central microclimatic station.

\subsection{Data analysis}

The effects of thinning and fertilization on different treatments were analyzed in the SAS statistical program (SAS system 9.1, SAS Institute Inc., Cary, NC, USA). Two-way ANOVA and ad-hoc pairwise Fisher's Least Significant Difference tests were used to test for treatment differences. When average soil respiration was analyzed, soil temperature at $10 \mathrm{~cm}$ depth was used as a covariate to adjust for temperature differences between treatments. Regression analysis was used to study the effects of thinning intensity on air and soil temperature.

\section{Results}

\subsection{Leaf Area Index}

Leaf area index (LAI) was on average 3.0 in the unthinned treatments in August 2004 (data not shown). The LAl was reduced by $51 \%$ and $84 \%$ in the $50 \%$ and $80 \%$ thinned 9263

treatments, respectively. No positive fertilization effects were noted on LAl at the end of the first growing season following spring fertilizer application (data not shown).

\subsection{Nutrient status and leaf morphology}

Nitrogen $(\mathrm{N})$ concentration in leaves ranged between treatments from 18.5 to $32.8 \mathrm{mg} \mathrm{N}$ 5 per gram leaf (Fig. 1). The spring fertilization had significantly increased $\mathrm{N}$ concentration in August $(P<0.001)$. Effects of thinning on nutrient status were more subtle and not significant across unfertilized treatments. However, when compared across fertilized treatments thinning did have a negative effect on $\mathrm{N}$ concentration $(P=0.01)$.

Mean leader shoot leaf size ranged from 8.5 to $19.9 \mathrm{~cm}^{2}$ between treatments in the 10 autumn (Fig. 2). Fertilization significantly increased leaf size $(P<0.001)$ while thinning had a negative effect on leaf size $(P=0.002)$. Specific leaf area (SLA) ranged from 74 to $85 \mathrm{~cm}^{2} \mathrm{~g}^{-1}$ but no statistical difference was noted between treatments (data not shown).

\subsection{Growth measurements}

15 Diameter at breast height ranged from 3.4 to $3.8 \mathrm{~cm}$ at the end of the first growing season (data not shown). Neither fertilization nor thinning affected diameter growth in the first growing season. Other growth measurements gave the same results in the first year of treatments (data not shown).

\subsection{Climate and soil temperature measurements}

20 Annual irradiance, temperature and precipitation in 2004 was $2487 \mathrm{MJ} \mathrm{m}^{-2}, 4.9^{\circ} \mathrm{C}$ and $991 \mathrm{~mm}$, respectively (Fig. 3). Mean monthly temperature ranged from $-2.1^{\circ} \mathrm{C}$ (December) to $12.1^{\circ} \mathrm{C}$ (July) and monthly precipitation ranged from $13.7 \mathrm{~mm}$ (October) to $158.2 \mathrm{~mm}$ (March), but remained relatively stable throughout the growing season (Fig. 3). The average precipitation was $2.7 \mathrm{~mm}$ per day. 
Air temperature at $50 \mathrm{~cm}$ height rose by $7 \%$ and $13 \%$ in the $50 \%$ and $80 \%$ thinned treatments, respectively (data not shown). This means that on a warm summer day of $+18^{\circ} \mathrm{C}$ in the unthinned treatments, the air temperature was $+19.3^{\circ} \mathrm{C}$ and $+20.3^{\circ} \mathrm{C}$ in the thinned treatments.

$5 \quad$ Thinning also increased soil temperature over the summer period, but the effects were more subtle than on air temperature (Fig. 4). The $50 \%$ and $80 \%$ thinned treatments had on average $1 \%$ and $7 \%$ higher soil temperatures, respectively, than the unthinned treatment (data not shown). Even though mean soil temperature did not increase as much as air temperature with thinning, there was a notable increase in

10 within-day fluctuations of soil temperature in the thinned treatments (data not shown).

\subsection{Soil respiration measurements}

Soil respiration in the treatments generally followed soil temperature as it rose from spring until the middle of August and declined thereafter, while the unthinned fertilized treatment had maximum respiration rates in July (Fig. 5).

15 Seasonal average soil respiration between treatments ranged from 2.03 to $3.15 \mu \mathrm{mol}$ $\mathrm{CO}_{2} \mathrm{~m}^{-2} \mathrm{~s}^{-1}$ (Fig. 6). Statistical analysis (Two-way ANOVA) revealed that thinning significantly lowered the soil respiration rate $(P=0.004)$, when compared across fertilization treatments. The reduction of soil respiration with thinning intensity was more pronounced in the unfertilized treatment (Fig. 6), even if the interaction between thinning and fertilization was not significant $(\mathrm{P}=0.37)$.

Two-Way ANOVA also showed that fertilization significantly increased soil respiration $(P=0.007)$, when compared across all three thinning treatments (Fig. 6). This was a valid observation for all thinning intensities, since the interaction term was not significant $\left(C^{*} \mathrm{~F}=0.37\right)$. When the thinning treatments were compared individually, it was

clear that the positive fertilization response increased with thinning intensity.

9265

\section{Discussion}

\subsection{Physical factors}

The precommercial thinning increased average soil and air temperatures within the stand and increased the daily fluctuations in temperature. Such responses were to be 5 expected as LAl and shading within the stand decreased (Aussenac, 2000; Thibodeau et al., 2000).

\subsection{Responses of trees}

Leaf $\mathrm{N}$ concentration in unfertilized plots (ca. $20 \mathrm{mg} \mathrm{Ng}^{-1}$ dry weight in the youngest fully expanded leaf) revealed that the natural $\mathrm{N}$ supply was low and $\mathrm{N}$ was a limiting 10 factor in tree growth. Sigurdsson (2001) found that $N$ limited tree growth when dry weight leaf $\mathrm{N}$ concentration was below $30 \mathrm{mg} \mathrm{g}^{-1}$.

No effects were noted on tree height and diameter growth in the first year of fertilization treatments. This slow growth response is in accordance with previous Icelandic forest management experiments (e.g. Óskarsson and Sigurgeirsson, 2001; Sigurdsson,

15 2001), where lag in fertilization response was observed. The only tree growth response in the first year was observed in the mean leaf size, which was significantly increased with fertilization. The average leaf size did, however, not increase as much in F-50 and $\mathrm{F}-80$ compared to $\mathrm{F}-00$. When trees grow in an environment where competition for light is high they often respond by growing larger and thinner leaves (Sigurdsson,

20 2001). Smaller leaf size in thinned fertilized treatments may show that competition for light was considerable in the unthinned plots and thinning was needed.

The negative response of leaf $\mathrm{N}$ to thinning intensity in the fertilization treatments was noteworthy, and maybe indicated more competitive understory $\mathrm{N}$ uptake with higher forest floor irradiance when tree LAl decreased or more immobilization of $\mathrm{N}$

25 by previously more temperature limited soil microorganisms. The latter was observed in a study by Thibodeau et al. (2000). 


\subsection{Soil respiration}

The results of the present experiment did only partly support the hypothesis that was being tested. We predicted that soil respiration would increase with thinning intensity, due to higher soil temperatures and increased litter input. Thinning was, however, 5 found to significantly reduce soil respiration during the first summer after treatments, and the reduction increased with thinning intensity. How can this be explained? Olsson et al. (2005) found that $63 \%$ of total soil respiration can be attributed to living tree roots in a Norway spruce stand in Sweden and similar results were recently reported by Korhonen et al. (2009) for Scots pine forest in Finland. Högberg et al. (2001) first

10 demonstrated that in northern forest ecosystems an unexpectedly large proportion of the soil respiration consists of recently fixed $\mathrm{CO}_{2}$ by canopy photosynthesis that has been translocated belowground and used by roots, mycorrhizae and exudation.

The thinning in the present study reduced tree density by $\sim 50 \%$ and $\sim 80 \%$, leading to similar relative reduction in LAI. This should have reduced photosynthesis per

15 area and the amount of respiring roots per area is likely to have reduced following the thinning. Therefore we believe the negative effects of thinning on soil respiration in our study to be the result of a reduction in the autotrophic root respiration and this effect was greater than any possible increase in heterotrophic respiration or understory root respiration. That the reduction of soil respiration increased with thinning intensity in the

20 present study strongly supports this hypothesis. The present study therefore gives an example of strong autotrophic control of soil respiration for northern deciduous forest, but most other studies have been done in coniferous stands (Högberg et al., 2001; Olsson et al., 2005; Tang et al., 2005; Korhonen et al., 2009).

Our initial hypothesis that fertilization would increase soil respiration was supported

25 by our findings. A recent meta-analysis by Knorr et al. (2005b) indicates that fertilization initially stimulates litter decomposition at sites with low ambient $\mathrm{N}$ deposition $\left(<5 \mathrm{~kg} \mathrm{ha}^{-1} \mathrm{year}^{-1}\right)$ and for high quality (low-lignin) litters, whereas decomposition rates are generally reduced at sites with moderate levels of $\mathrm{N}$ deposition $\left(5-10 \mathrm{~kg} \mathrm{ha}^{-1}\right.$

9267

year $\left.{ }^{-1}\right)$. The $\mathrm{N}$-decomposition in Iceland is low, or generally $<1.5 \mathrm{~kg} \mathrm{Nha}^{-1} \mathrm{year}^{-1}$ (Gíslason et al., 1996). Our results are therefore in accordance with previous findings on the initial fertilization response on soil respiration at higher latitudes, where the $\mathrm{N}$-supply is a limiting factor in forest ecosystems (Hyvönen et al., 2007). It should,

5 however, be stated that some recent studies have shown that the long-term fertilization in northern forests may decrease the rate of decomposition and soil respiration (e.g. Hyvönen et al., 2007).

Temperature and moisture have been found to play an important role in seasonal patterns of soil respiration (Ma et al., 2005). As was previously mentioned, the soil 10 water potential has been found to be permanently close to field capacity at the present site (Strachan et al., 1998), and water availability was therefore not considered to limit tree growth or ecosystem processes. Therefore, temperature is likely the key determent of seasonality in soil respiration at the site, as was indeed indicated by similar seasonal fluctuations in seasonal soil respiration and temperature for all treatments.

\section{Conclusions}

It was expected that precommercial thinning and fertilization would have an immediate additive effect on soil respiration, due to higher soil temperatures and increased litter input. The data showed that fertilization indeed increased soil respiration, but thinning intensity decreased it. This occurred even though soil temperatures rose with thinning 20 and all organic material was left at site. This response was interpreted as a signal from decreased autotrophic root respiration in the thinned stands; a response missing in most or all simulation models of the carbon cycle in managed forests. Hence, these results may be important when the effects of early forest management on carbon fluxes are modeled. 
Acknowledgements. Mogilsa - Icelandic Forest Research and the Soil Conservation Service of Iceland are thanked for providing logistic support during the present study. The Icelandic Research Council (Rannís), CAR-ES (Centre of Advanced Research on Environmental Services) and The Southern Region Institute for Advanced Learning provided funding for the study.

5 The first author especially acknowledges prof. Kesara Anamthawat-Jónsson at Univ. of Iceland, who acted as his main supervisor. Also thanks to Michael Freeman, Hlynur Óskarsson, Jón Gudmundsson and Arnór Snorrason for their opinions and feedback.

\section{References}

Aradottir, A., Thorgeirsson, H., McCaughey, J. H., Strachan, I. B., and Robertson, A.: Establishment of a black cottonwood plantation on an exposed site in Iceland: plant growth and site energy balance, Agric. For. Meteorol., 84, 1-9, 1997.

Aussenac, G.: Interactions between forest stands and microclimate: Ecophysiological aspects and consequences for silviculture, Ann. For. Sci., 57, 287-301, 2000.

Bjarnadóttir, B.: Carbon stocks and fluxes in a young Siberian larch (Larix sibirica) plantation in Iceland, Ph.D. thesis, Department of Physical Geography and Ecosystem Analysis, Lund University, Lund, Sweden, 62 pp., 2009.

Boone, R. D., Nadelhoffer, K. J., Canary, J. D., and Kaye, J. P.: Roots exert a strong influence on the temperature sensitivity of soil respiration, Nature, 396, 570-572, 1998.

Castro, M. S., Peterjohn, W. T., Melillo, J. M., and Steudler, P. A.: Effects of nitrogen fertilization on the fluxes of $\mathrm{N}_{2} \mathrm{O}, \mathrm{CH}_{4}$, and $\mathrm{CO}_{2}$ from soils in a Florida slash pine plantation, Can. J. For. Res., 24, 9-13, 1994.

Cleveland, C. C. and Townsend, A. R.: Nutrient additions to a tropical rain forest drive substantial soil carbon dioxide losses to the atmosphere, PNAS, 103, 10316-10321, 2006.

Fan, S., Gloor, M., Mahlman, J., Pacala, S., Sarmiento, J., Takahashi, T., and Tans, P.: A large

25 terrestrial carbon sink in North America implied by atmospheric and oceanic carbon dioxide data and models, Science, 282, 442-446, 1998.

Gíslason, S. R., Arnórsson, S., and Ármannsson, H.: Chemical weathering of basalt in southwest Iceland: effects of runoff, age of rocks and vegetative/glacial cover, American J. Sci., 296, 837-907, 1996.

30 Hanson, P. J., Edwards, N. T., Garten, C. T., and Andrews, J. A.: Separating root and soil mi-

9269

crobial contributions to soil respiration: a review of methods and observations, Biogeochem., 48, 115-146, 2000.

Högberg, P., Nordgren, A., Buchmann, N., Taylor, A. F. S., Ekblad, A., Högberg, M. N., Nyberg, G., Ottoson-Löfvenius, M., and Read, D. J.: Large-scale forest girdling shows that current photosynthesis drives soil respiration, Nature, 411, 789-792, 2001.

Hyvönen, R., Ågren, G. I., Linder, S., Persson, T., Cotrufo, M. F., Ekblad, A., Freeman, M., Grelle, A., Janssens, I. A., Jarvis, P. G., Kellomäki, S., Lindroth, A., Loustau, D., Lundmark, T., Norby, R. J., Oren, R., Pilegaard, K., Ryan, M. G., Sigurdsson, B. D., Strömgren, M., van Oijen, M., and Wallin, G.: The likely impact of elevated $\left[\mathrm{CO}_{2}\right]$, nitrogen deposition, in-

10 creased temperature and management on carbon sequestration in temperate and boreal forest ecosystems: a literature review, New Phytol., 171, 275-296, 2007.

IPCC: Summary for Policymakers. Forth Assessment Report. Working Group I. In: Climate Change 2007: The Physical Science Basis. Contribution of Working Group I to the Fourth Assessment Report of the Intergovernmental Panel on Climate Change, edited by: Solomon,

15 S., Qin, D., Manning, M., Chen, Z., Marquis, M., Averyt, K. B., Tignor, M., and Miller, H. L., Cambridge University Press, Cambridge, United Kingdom and New York, NY, USA., 2007.

Jarvis, P., and Linder, S.: Constraints to growth of boreal forests, Nature, 405, 904-905, 2000.

Kirschbaum, M. U. F.: The temperature dependence of soil organic matter decomposition, and the effect of global warming on soil organic C storage, Soil Biol. Biochem., 27, 753-760, 1995.

Knorr, M., Frey, S. D., Curtis, P. S.: Nitrogen additions and litter decomposition: a meta-analysis, Ecol., 86, 3252-3257, 2005b.

Knorr, W., Prentice, I. C., House, J. I., and Holland, E. A.: Long-term sensitivity of soil carbon turnover to warming, Nature, 433, 298-301, 2005a.

25 Korhonen, J. F. J., Pumpanen, J., Kolari, P., and Juurola, E.: Contribution of root and rhizosphere respiration to the annual variation of carbon balance of a boreal Scots pine forest, Biogeosci., [in press in this special issue], 2009.

Linder, S.: Foliar analysis for detecting and correcting nutrient imbalances in Norway spruce, Ecol. Bull., 44, 178-190, 1995.

30 Liski, J., Ilvesniemi, H., Mäkelä, A., and Westman, C. J.: $\mathrm{CO}_{2}$ emissions from soil in response to climatic warming are overestimated - The decomposition of old soil organic matter is tolerant of temperature, Ambio, 28, 171-174, 1999.

Luo, Y. and Zhou, X.: Soil Respiration and the Environment. Elsevier, San Diego, CA, 2006. 
Ma, S., Chen, J., Butnor, J. R., North, M., Euskirchen, E. S., and Oakley, B.: Biophysical controls on soil respiration in dominant patch types of an old growth mixed conifer forest, For. Sci., 51, 221-232, 2005.

Olsson, P., Linder, S., Giesler R., and Högberg, P.: Fertilization of boreal forest reduces both

5 autotrophic and heterotrophic soil respiration, Global Change Biol., 11, 1-9, 2005.

Óskarsson, $\mathrm{H}$. and Sigurgeirsson, A.: Fertilization in Icelandic afforestation: evaluation of results, Scand. J. For. Res., 16, 536-540, 2001.

Raich, J. W., Potter, C. S., and Bhagawati, D.: Interannual variability in global soil respiration, 1980-94, Global Change Biol., 8, 800-812, 2002.

10 Ryan, M. G. and Law, B. E.: Interpreting, measuring, and modeling soil respiration, Biogeochem., 73, 3-27, 2005.

Selmants, P. C., Hart, S. C., Boyle, S. E., Gehring, C., and Hungate, B. A.: Restoration of a ponderosa pine forest increases soil $\mathrm{CO}_{2}$ efflux more than either water or nitrogen additions, J. Appl. Ecol., 45, 913-920, 2008.

15 Sigurdsson, B. D.: Environmental control of carbon uptake and growth in a Populus trichocarpa plantation in Iceland, Acta Univ. Agricult. Suec., Silvestria, 174, 64 pp., 2001.

Sigurdsson, B. D., Thorgeirsson, H., and Linder, S.: Growth and dry-matter partitioning of young Populus trichocarpa in response to $\mathrm{CO}_{2}$ concentration and mineral nutrient availability, Tree Physiol., 21, 941-950, 2001.

20 Siira-Pietikäinen, A., Pietikäinen, J., Fritze, H., and Haimi, J.: Short-term responses of soil decomposer communities to forest management: clear felling versus alternative forest harvesting methods, Can. J. For. Res., 31, 88-99, 2001.

Snorrason, A., Sigurdsson, B. D., Gudbergsson, G., Svavarsdottir, K., and Jonsson, H.: Carbon sequestration in forest plantations in Iceland, Icelandic Agric. Sci., 15, 81-93, 2002.

25 Strachan, I. B., Arnalds, Ó., Pálmason, F., Thorgeirsson, H., Sigurdsson, B. D., Sigurdardóttir, H., and Novoselac, G.: Soils of the Gunnarsholt experimental plantation, Icelandic Agric. Sci., 12, 27-38, 1998.

Sullivan, B. W., Kolb, T. E., Hart, S. C., Kaye, J. P., Dore, S., and Montes-Helu, M.: Thinning reduces soil carbon dioxide but not methane flux from southern USA ponderosa pine forests, For. Ecol.Managem., 255, 4047-4055, 2008.

Tang, J., Qi, Y., Xu, M., Misson, L., and Goldstein, A. H.: Forest thinning and soil respiration in a ponderosa pine plantation in the Sierra Nevada, Tree Physiol., 25, 57-66, 2005.

Thibodeau, L., Raymond, P., Camiré, C., and Munson, A. D.: Impact of precommercial thinning

9271

in balsam fir stands on soil nitrogen dynamics, microbial biomass, decomposition, and foliar nutrition, Can. J. For. Res., 30, 229-238, 2000.

Toland, D. E. and Zak, D. R.: Seasonal patterns of soil respiration in intact and clearcut northern hardwood forests, Can. J. For. Res., 24, 1711-1716, 1994. 


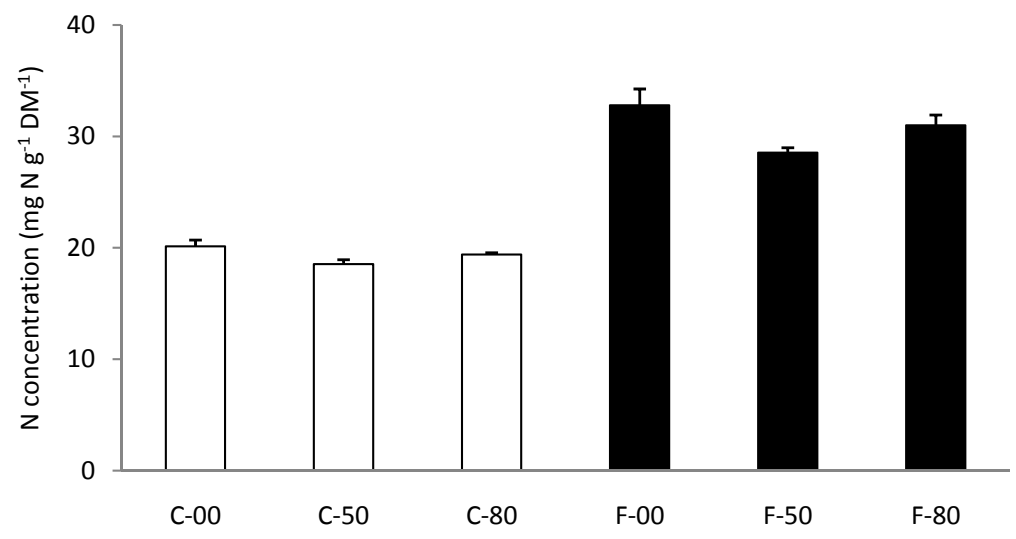

Fig. 1. Mean $\mathrm{N}$ concentration per $\mathrm{g}$ leaf in the youngest fully developed leaves of Populus trichocarpa canopy in August 2004 in unfertilized or fertilized (C or F) treatments with different thinning intensities $(0 \%, 50 \%, 80 \%)$. Each bar represents an average \pm SE of $n=14$.

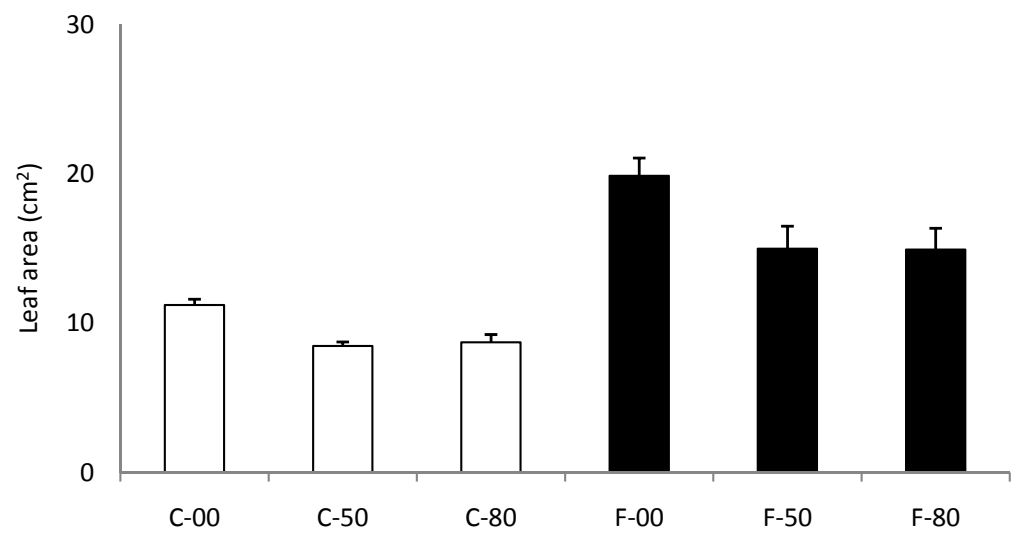

Fig. 2. Average leader shoot leaf size $\left(\mathrm{cm}^{2}\right)$ of Populus trichocarpa canopy in August 2004 in unfertilized or fertilized ( $C$ or $F)$ treatments with different thinning intensities $(0 \%, 50 \%, 80 \%)$. Each bar represents an average \pm SE of $n=6$. 

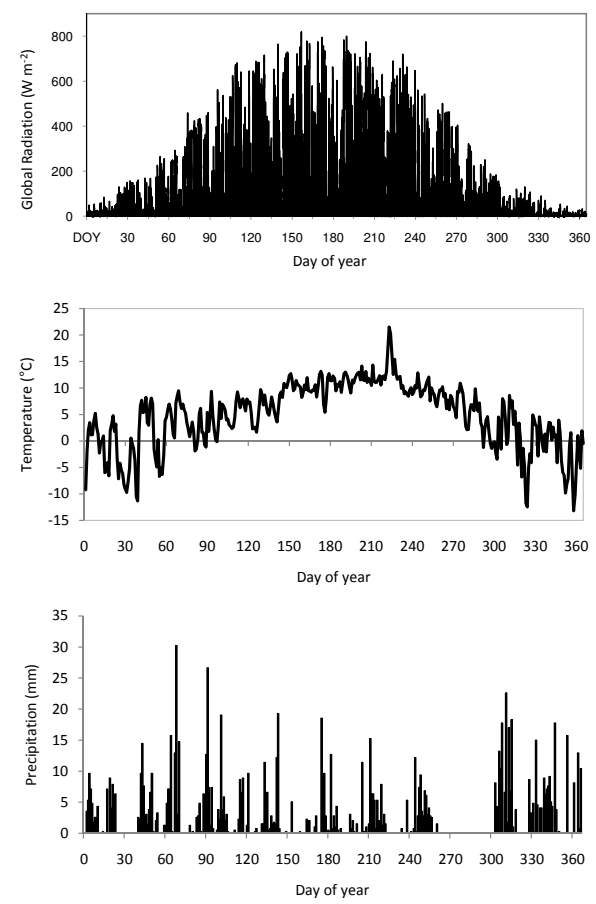

Fig. 3. Daily global radiation above canopy (top panel), mean daily air temperature $\left({ }^{\circ} \mathrm{C}\right)$ at $2 \mathrm{~m}$ height (middle panel) and daily precipitation (bottom panel) measured in the Populus trichocarpa experimental plantation in 2004.

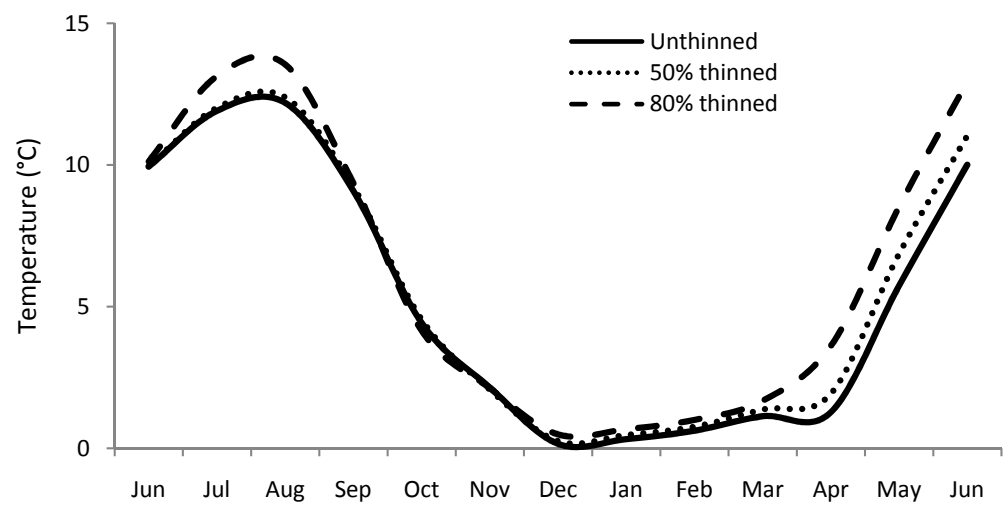

Fig. 4. Soil temperature $\left({ }^{\circ} \mathrm{C}\right)$ in different thinning treatments at $10 \mathrm{~cm}$ depth over one year period from establishment. The measurements are averages of $n=2$. 


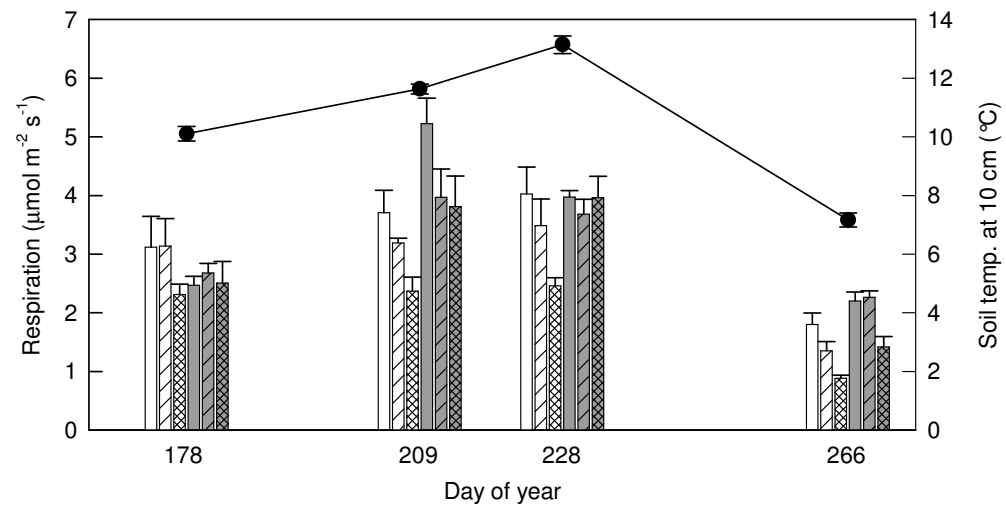

Fig. 5. Seasonal changes in soil respiration rates and mean soil temperature at $10 \mathrm{~cm}$ depth (line) of Populus trichocarpa plots in unfertilized (no fill) or fertilized (grey fill) treatments with unthinned (no pattern), 50\% thinned (diagonally hatched) and $80 \%$ thinned (crosshatched) during the growing season in 2004 (22 June to 22 September) Each bar represents an average \pm SE of $n=4$.

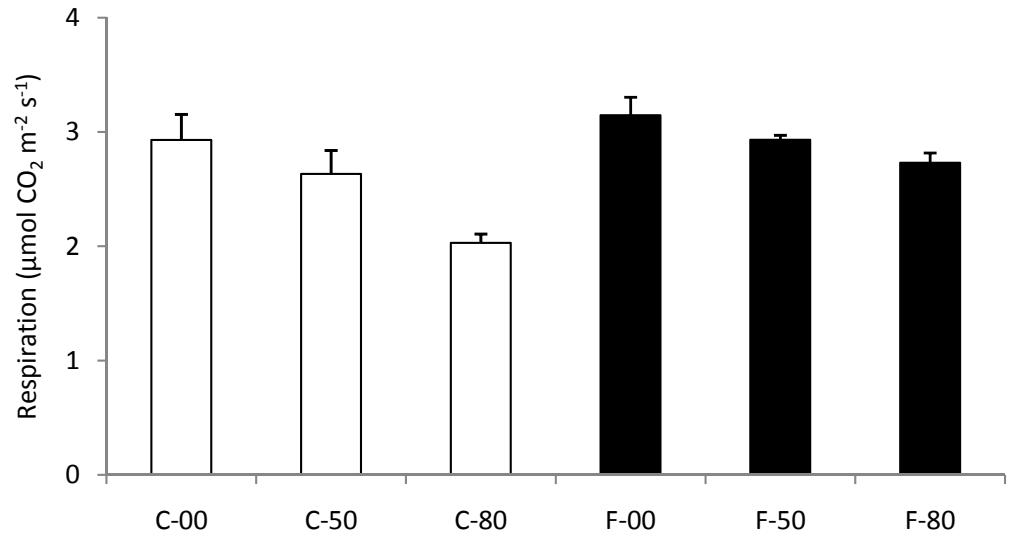

Fig. 6. Seasonal average soil respiration rate of Populus trichocarpa plots in unfertilized or fertilized ( $\mathrm{C}$ or $\mathrm{F})$ treatments with different thinning intensities $(0 \%, 50 \%, 80 \%)$ during the growing season in 2004. Each bar represents an average \pm SE of $n=4$. 